\title{
Imaginar las Postrimerías: escrituras chilenas de los confines
}

\section{Imagining the Afterlife: Chilean Writings from the Confines}

\author{
Alejandra Bottinelli Wolleter \\ Universidad de Chile \\ alejandra.bottinelli@u.uchile.cl
}

\section{Resumen}

El ensayo indaga sobre las formas en que algunas escrituras chilenas de la última década han producido la escena liminar del fin de los tiempos, del fin del mundo y sus postrimerías. Interesa preguntar sobre cómo estas ficciones imaginan la crisis actual desde los espacios disruptivos, movedizos y también "excepcionalizados" de los confines, y cómo producen, a través del género apocalíptico "enmascarado, cifrado" (Derrida), otra imaginación del presente, una crítica política que, evidenciando la crisis del presente como crisis de la imaginación del futuro, podría reconducir nuestra mirada sobre los límites de nuestro tiempo y las condiciones de su superación. El ensayo intenta, asimismo, pensar esas escrituras de manera situada, desde una enunciación también en crisis, que asume lo contemporáneo en un trance de caída y trasformación.

Palabras clave: Escrituras chilenas recientes, confines, postrimerías, crisis, futuro.

\section{Abstract}

The essay investigates the ways in which some Chilean writings of the last decade have produced the limit scene of the end of times, the end of the world, and its afterlife. It is interesting to inquire how these fictions imagine the current crisis from the disruptive, shifting and also "exceptionalized" spaces of the boundaries of the end (confines, in Spanish), and how they produce, through the apocalyptic genre "masked, encrypted" (Derrida), another imagination of the present. A political critique that, revealing the current crisis as a crisis of the imagination of future, could re-guides our gaze on the limits of our time and the conditions for its overcoming. The essay also tries to think about these writings in a situated way, from an enunciation also in crisis, which assumes the contemporary in a trance of fall and transformation.

Keywords: Recent Chilean writings, confines, afterlife, crisis, future. 
“El fuego está lleno de habitantes.

Vamos

hacia ellos.

Volvamos

Intactos".

Fernando Navarro Geisse

Traigo un mensaje: el mundo se quema, el mundo es una bola agónica que se deshace por sus lados blandos y sólidos. Los cuatro elementos se agreden, se asesinan unos a otros: el agua se está achicharrando en petróleo, la tierra se pudre estercolada y el aire sufre con líquidos ácidos que van a dar a la tierra como fuego que ya nunca se apagará. Seremos juzgados, les cuento. Traigo un mensaje. Yo se los traigo.

Como bien ha mostrado un pensador que reflexionó sobre la matriz del discurso apocalíptico, el mensajero pareciera obtener aquí un cierto beneficio de su papel de mistagogo escatológico, ${ }^{1}$ es decir, de ser quien devela el misterio del fin de los tiempos que está viniendo. El término escatología, como ha explicado Jacques Le Goff, refiere a la doctrina de los fines últimos, es decir, al cuerpo de las creencias relativas al destino de los seres humanos y del universo. ${ }^{2}$ Los apocalipsis, por su parte, género literario característico de la escatología, proceden en general bajo forma de visiones, pero el tiempo del fin es a menudo evocado bajo forma profética $(46,50)$. Esta unidad entre escatología y profetismo es común en la historia y en ella encuentran su lugar las escrituras que actúan vaticinando, visionando en el presente las marcas y claves del fin que viene, y que, por ello, tienden a la elaboración de símbolos que prefiguran el futuro en el tiempo que queda. Porque el presente se vuelve así, un tiempo restante, no sustantivo, adosado al fin del cual es anuncio, amenaza; tiempo rehén de una razón que siempre refiere a un más allá, el presente se vuelve una epifanía del futuro, su aparición necesaria, y no al revés. Un presente que, crecidamente simbólico y, a la vez, altamente estructurado y cerrado sobre sí, puede quedar reducido en su potencia creativa de transformación. El hoy así pasado por el cedazo escatológico se observa en su espejo como un fantasma

1 Uso la imagen de Jacques Derrida (párr. 18 y ss.): “Mistagogo" proviene del griego " $\mu \nu \sigma \tau \alpha \gamma \omega \gamma \iota \alpha$ ” (mystagōgia), formado por " $\mu \nu \sigma \tau \eta \varsigma$ " (mystēs), iniciador, y " $\alpha \gamma \omega \gamma o \varsigma^{\prime}$ (agōgós), el que impulsa. Para la Iglesia católica, mistagogia es el tiempo, después del bautismo, en el que los nuevos nacidos en Cristo son iniciados en varios misterios (sacramentos) del catolicismo. Mistagogos son aquellos, enfatiza Derrida, que "se dicen en relación inmediata e intuitiva con el misterio [...y $]$ quieren atraer, seducir, conducir hacia el misterio y por el misterio” (párr. 24).

2 Algunos especialistas lo usan en singular, como "acontecimiento final", precisa Jacques Le Goff (46). "La escatología ha estado precisándose a través de las narraciones de naturaleza profética que describían una [...] 'revelación' de los acontecimientos del fin de los tiempos. Estas narraciones hebraico-cristianas han sido, en su mayor parte, escritas en los siglos inmediatamente precedentes a la era cristiana y en los primeros siglos de esta era; uno de ellos, el Apocalipsis de Juan, ha sido introducido por el cristianismo en el corpus del Nuevo Testamento. Dada la considerable importancia asumida por estos escritos, ya desde el punto de vista dogmático, ya desde el histórico, la apocalíptica está estrechamente ligada a la escatología" (48). 
que desde el futuro viene a buscarnos no para llevarnos al otro lado del espejo, sino para mostrarnos tautológicamente que la realidad-real del presente es el límite y su anunciación, es decir, un tiempo que se consume a sí mismo como tal tiempo. Y más allá, las Tinieblas.

O no. Porque el relato escatológico y apocalíptico, concentrado en la escena liminar del fin del mundo y alojado topológicamente en la realidad (siempre disruptiva, movediza pero también "excepcionalizada") de los confines, de las esquinas del mundo, puede también implicar la imaginación de un nuevo origen, probablemente múltiple y anacrónico, ${ }^{3}$ que reelabore las formas de relación no solo temporales sino también espaciales. Pues en el confín, frontera muchas veces abandonada y desconsiderada, límite siempre lejano, se juega a diario el envés del orden de la historia. $\mathrm{O}$, mejor, más precisamente, al modo borgeano, en las "orillas", en esa realidad más real que es el espacio imaginario liminal que expone el cruce de todos los caminos, la escena del margen sin centro donde habita la mezcla, la ambigüedad, y el doblez; donde los caminos están todos por hacerse, como lee Beatriz Sarlo. ${ }^{4}$

Y además porque, como bien apunta Jacques Derrida, este género apocalíptico “enmascarado, cifrado" (párr. 81), se instituye también como una forma de producir otra imaginación del propio presente, una crítica política que muestre la crisis del presente como crisis de la propia imaginación del futuro, y que, desordenando las genealogías (algo que realizan recurrentemente las escrituras chilenas recientes), puede reconducir nuestra imaginación del límite al ubicarnos en esa escena liminar, no solo alertarnos simbólicamente sobre ese límite en un presente como colección de indicios, sino permitirnos pensar ese más allá, esa escena de las postrimerías y de la crisis que desenvuelve nuestras más grises medianías, nuestras definiciones indecibles. Imaginar un límite, eso permiten sobre todo las escrituras recientes, que juegan en la paradoja de un futuro que está ocurriendo.

Entonces, o nos quedamos con el susurro del mensajero que dice: "Estamos solos en el mundo, yo soy el único que te puede revelar la verdad o el destino, yo te la digo, yo te la doy, ven, seamos un instante, nosotros que no sabemos aún que somos, un instante antes del fin los únicos sobrevivientes, los únicos que velan” (Derrida párr. 64), y en ese su anuncio de sí mismo como revelador del secreto y formador de una comunidad de ese secreto, o nos entregamos a la imaginería de los confines, a la frágil y peligrosa escena de las orillas donde todo puede pasar porque estamos justamente en la vivencia del fin, en la imaginación de las postrimerías, ${ }^{5}$ es decir, de los últimos

3 "La memoria es psíquica en su proceso, anacrónica en sus efectos de montaje", afirma Georges Didi-Huberman (Ante el tiempo 60).

4 Dice Beatriz Sarlo: "En 'las orillas', la ciudad está todavía por hacerse. Borges escribe un mito para Buenos Aires que, en su opinión, andaba necesitándolos. Desde un recuerdo que casi no es suyo, opone a la ciudad moderna, esta ciudad estética sin centro, construida totalmente sobre la matriz de un margen" (38) y "Las orillas amenazadas de la literatura están en cualquier parte de la ciudad, precisamente porque el margen que son no tiene centro" (38).

5 Postrimería se formó de latín "postrēmus", "último" (Corominas 471). En el catecismo católico se refiere a las fases que los seres humanos deben pasar hacia el fin de sus días: muerte, juicio (o Purgatorio), Infierno, Paraíso o Gloria. 
tiempos donde las humanas y humanos que somos nos hemos volteado de revés para evidenciar nuestras frías o viscosas manías, nuestros atavismos, nuestra naturaleza ambivalente y des-aforada (fuera del foro: del público, de la comunidad).

\section{La crisis 6}

Cosas junto a otras cosas. Una silla desvencijada al sol y a su lado un cigarro que se consume hasta la ceniza; un niño juega solo en una plaza DESIERTA, árboles se mecen, ajenos; una camioneta en medio de un paisaje frío, en su pickup, una pala: abandono, soledad, peligro, desaparición, MIEDO, estamos acostumbrados a determinadas cosas que, asociadas con otras, significan inmediata e indudablemente; miles de segmentos cinematográficos de malas y no tan malas películas han usado estas metonimias. De la misma manera, en nuestro imaginario chileno de las últimas décadas las cosas se venían aliando a otras cosas de maneras más o menos previsibles. Un CANSANCIO de siglos se iba acumulando en las almas. Como la imagen dialéctica de Walter Benjamin, se hacía imperativo algo que interceptara este continuum, que "trazara una línea de fractura o un intervalo entre las cosas" (Oviedo 21) e hiciera saltar esa fastidiosa repetición. Que rompiera esa certeza, dura como la costra terrosa y DESARBOLADA de las ORILLAS de Santiago, que se asentaba en nuestra idea: ya no vendría nada nuevo o, al menos, nada mucho mejor; lxs jóvenes se habían acostumbrado al bling-bling y a la POLICÍA, los pobres a vivir de prestado al crédito, y las izquierdas se acicalaban.

Hasta que todo estalló. Un día, después de cientos de humillaciones y pequeños y no tan pequeños golpes a los colegios públicos, lxs chiquillxs del centro de Santiago se echaron a CORRER. Y corrieron y corrieron. Desde los ASEDIADOS muros de los liceos saltaron todas las barreras del orden chileno y dijeron sanseacabó. Todo terminó y comenzó con ellxs, cuando se echaron a correr. Pasaron muchas cosas más, de las que no me atrevo a hablar porque de eso se trata también este trabajo, de lo difícil que es narrarnos en el tiempo cuando hemos vivido A SALTOS; pasar por sobre la PIEL del tiempo que hemos y nos ha interceptado y contarla como crónica,

6 La crisis a la que aquí refiero es la crisis chilena abierta como tal "crisis" desde el 18 de octubre de 2019. Para comprender algunas de sus condiciones de apertura, véanse los libros de Óscar Contardo, Antes de que fuera octubre (2020), La caída del jaguar: crónica del estallido social en Chile, de Gonzalo León (2020), así como el trabajo de crónica poetizada que durante el proceso mismo realizó el músico chileno Nano Stern, publicado como Décimas del estallido: crónica en verso de la rebelión chilena, con ilustraciones de Marcelo Escobar Morales (2020). La crisis chilena, por otra parte, se enmarca en una crisis de carácter global que tempranamente Félix Guattari había caracterizado: "Hay que estimar que lo esencial de esa crisis mundial (que es, al mismo tiempo, una especie de guerra social mundial) es la expresión de la gigantesca ascensión, por toda la superficie del planeta, de toda una serie de sectores marginados. Centenas de millares de personas viven con hambre, y no sólo eso, sino también centenas de millares de personas no pueden reconocerse en los cuadros sociales que les son propuestos. Esa crisis de los modelos de vida, de los modelos de sensibilidad, de los modelos de relaciones sociales, no existe sólo en los países 'subdesarrollados' más pobres. Existe también en amplias corrientes de masas de los países 'desarrollados'” (Guattari y Rolnik 217). 
dar cuenta de ella como transcurso homogéneo, ${ }^{7}$ como si fuera el tiempo un relato consistente y no nosotrxs mismxs interceptando, DISLOCANDO toda continuidad posible, como ha ocurrido en este tiempo. Porque escribir la crisis también importa la imposibilidad de no extrañarnos en la escritura, de no perdernos cada vez en ella, de no desconocernos allí donde ni nosotrxs mismxs nos reconocemos ya, porque ni nosotrxs mismxs somos capaces de apresar la POTENCIA que nos habita (y con extrañamiento me refiero a ese que es, a la vez, tanto la separación y la DISTANCIA brechtianas, como el exilio y el confinamiento). Esa sensación de extrañamiento me CIERRA la boca cuando debo decir lo que hemos vivido como crisis. Porque es todavía un MISTERIO. Porque estamos en la crisis. Ha pasado tan solo un año y es un Chile tan distinto, tan lejano, enhorabuena, tan misterioso.

Lo que puedo decir es el ANTES. Antes de que lxs chiquillxs de los liceos salieran disparadxs corriendo y saltándose todo, por mi lado estaba pensando difusamente sobre el FUTURO. Por supuesto del futuro ECOLÓGICO, que es en verdad el futuro como tal; y también del futuro como idea, que veía que se MORÍA en la imaginación, por un revival de las "muertes de la historia" que nos susurraba que el capitalismo ya nos dominaba verticalmente de manera absoluta avisando en nuestras pantallas lo que esperábamos del mañana, y se imponían las llamadas “políticas de la anticipación”. En septiembre había presentado en Valparaíso un texto que tenía un título superpretensioso ${ }^{8}$ en el que afirmaba la convicción de que la imaginación crítica existiría solo en la conservación del misterio del futuro y de la escritura como VIBRACIÓN que resguardase la potencia DE-NO de ese misterio, al modo que propone Agamben (El fuego 40). Pero en ese momento, antes del $18 \mathrm{O}$ (sin guion: ese cambio de dirección, el giro en 180 grados de esta historia), el fututo funcionaba en mí como una creencia, CREÍA en esa vibración y sostenía, JUNTANDO LAS MANOS, que ella funcionaba sobre todo como un pensar de la espera, de la paciencia, y que lo que tocaba todavía por un largo tiempo era seguir alimentando esa potencia con GESTOS, en una espera, que aunque activa, era un repliegue del cuerpo. ${ }^{9} \mathrm{Mi}$ esperanza era más bien racional, LIBRESCA. No tenía referentes. Nunca había vivido una REVUELTA popular. A las semanas TODO giró, después de octubre ya nada esperó, todo se trataba de ir, de marchar, de CORRER, de ocupar las ESQUINAS, de PROPAGARSE, de EXTENDERSE con el CUERPO. Y entonces, la crisis estaba ahí, aquí, en todas partes, y todo estaba en crisis, la crisis nos envolvió y nos modificó.

7 La memoria pareciera funcionar en el montaje, y en el encuentro azaroso de tiempos heterogéneos, como ha pensado Didi-Huberman (Ante el tiempo 61).

8 "Futuro y misterio de la imaginación crítica". Coloquio "Estética y Justicia. Homenaje a Julio Ramos". 25 de septiembre de 2019. Auditorio centex, Valparaíso.

9 Decía Karl Kraus cuando imaginaba su tarea en la situación de decadencia de la cultura liberal europea de su época: “[...] un impulso satánico me seduce a esperar y a aguantar aquí mismo la evolución de las cosas hasta que llegue el día de la ira y finalicen los mil años. Hasta que el dragón quede suelto y una voz desde las nubes me llame diciendo: ¿Vuela conmigo, excelencia?”” (45). 
Una crisis que venía de antes, sí, que estaba presente en miles de agenciamientos críticos sobre nuestro presente (y futuro). Lo que se mostraba ahora, lo que se PRESENTABA $^{10}$ ante nosotrxs era la necesidad de la acción que exigía esa crítica. Era este, como enseñaba otro pensador, el momento cúlmine del proceso crítico, el momento mismo de la crítica, el de la DEFINICIÓN pero cuando esta aún se mantiene en SUSPENSO, este interregno, como dice Koselleck, en que el "proceso crítico se halla ya en su término, y resulta inevitable una decisión, aunque esta todavía no ha tenido lugar [...y] la crisis se torna, de este modo, manifiesta. En la crítica se oculta la crisis" (97). ${ }^{11}$ La crítica era la crisis y ese tiempo, el de la decisión. Y así cada día pasaba no como un día sino como muchos días y, por ello, paradojalmente como uno solo, un solo largo día, una crónica de un largo día, SIN FINAL. Pues todo estaba abierto, todo estaba AL AIRE, como decimos. El futuro estaba de vuelta, se presentaba, ante la cara. Un futuro terrible y también HERMOSO, a la vez.

Entonces, todo fue volver a Chile, que de a poco sentimos menos lejos. Las lecturas y las escrituras volvían a ser las chilenas. En ellas había alojado un misterio. Un misterio nuevo. Algo pasaba en EL CHILE DE LAS ESQUINAS, de las ORILLAS del modelo que yo no había sido capaz de IMAGINAR. Pero tal vez otrxs sí, no en soledad, en colectivos: textos ENREDADOS a otros que eran esa imaginación colectiva de la crisis. ${ }^{12}$

He leído en estos meses en ciertas escrituras de la provincia chilena, en alguna poesía de los EXTRAMUROS de la ciudad, en textos que andan sobre futuros apocalípticos y pasados de maneras anacrónicas, algunos indicios de la crisis. Como en un CAJÓN de niñx en el que esos textos se hallaban todos mezclados, emergen de ellos retazos de nuestra crisis. En esas escrituras que, además, funcionan en el LÍMITE de nuestros imaginarios del lugar y del tiempo, se podía encontrar inscrito mucho de ese afuera de la espera que ahora se nos metía ADENTRO en la crisis. Se metía adentro, no ya como había pensado antes, no como algo muerto que te meten dentro, como nos pasaba a nosotrxs, lxs hijxs, ${ }^{13}$ sino adentro como

10 ¿QQué nos dice la palabra 'presentación’? Que algo está ante a nosotros, se encuentra frente a nosotros como un cuerpo [...] Sentir que una cosa se presenta - a diferencia de un simple objeto que estuviera 'posado' o 'colgado' ante nosotros- es experimentar el en-frente de su corporeidad [...] esta constricción supone [...] la instauración de un lugar" (Didi-Huberman, Falenas 208-209).

11 "Krísis proviene del verbo griego kríno: 'separar', 'escoger,' 'enjuiciar,' 'decidir'; en voz media, 'medirse', 'luchar', 'combatir' [...] En griego, la palabra formaba parte de los conceptos fundamentales de la política. Significaba 'separación’ y 'lucha', pero también ‘decisión', en el sentido de una inclinación definitiva de la balanza” (Koselleck 241).

12 Esos mismos, los imaginarios que van a estallar luego, en la crisis, como arrasados por un torrente profético heterogéneo y proteico por la imaginación popular chilena, que hubo roto una tras otra las rutinarias asociaciones a las que nos habíamos acostumbrado. Baste solo aquella imagen de un enjambre que, con traducción japonesa, daba inicio a un "Neo-Chile" en una plaza que tiene por nombre DIGNIDAD. O la visión de ese millón de personas que, resguardadas por una línea de defensa compuesta por jóvenes sosteniendo escudos hechos con antenas de TV cable, tarros y calaminas, corea "El pueblo unido, jamás será vencido", mientras al frente le apuntan a sus ojos. O la consigna Hasta que valga la pena vivir rayada en muros aquí, allá, en toda parte. La crítica es la crisis. NADA SE REPITE.

13 Como hemos escrito en otra ocasión, "la memoria que era de ellos no la tenemos, ésa es solo una parte muerta que uno deja dentro de otro" (Bottinelli 20). Igualmente, en Los hijos suicidados de Gabriela Mistral, una imagen 
algo VIVO que CRECÍA en ti, un monstruo o un niñx, o mejor, como un niñx monstruo, SIN FAZ aún.

\section{La imaginación de los confines}

Decíamos arriba que el relato escatológico de la imaginación del fin se juega ya en la exclusividad (y poder) del secreto que guardamos algunos que, "señalados", seguimos al mensajero mistagogo que nos convoca a velar por el futuro, ya en la imaginación del espacio mucho menos seguro, frágil, de las orillas de nuestro mundo, de los lindes, donde imaginar las postrimerías es a la vez habitar los confines, es decir, donde el fin de nuestro tiempo se extiende como habitación en el fin de mundo, tierra y paisaje del último lugar.

Para el estado moderno, el confín ha tenido una función fundamental en la protección y vigilancia de la soberanía (Campesi 167). En el contexto global actual, estos espacios fronterizos, de cruce y de paso han sido objeto de nuevas tecnologías de control, incluidas modalidades biopolíticas para el manejo de los flujos de poblaciones y mercancías consideradas amenazantes o extraterritoriales. En estos confines, donde la vida se halla supeditada a las decisiones coyunturales de los poderes seguritarios - sobre todo policiales_, se vive muchas veces en la suspensión del derecho y de la política — como deliberación, como polis - ${ }^{14}$. La dinámica del confín, sin embargo, no se reduce a su espacio, sino que funciona multiplicándose como modelo de control biopolítico por todo el ordenamiento social, jurídico y simbólico. Como explica Giuseppe Campesi:

[L]os confines parecen ofrecer una precisa consistencia espacial a la idea schmittiana de Estado de excepción, funcionando como "territorio excepcional" situado en los márgenes del ordenamiento jurídico. El confín se describe, en este caso, como un espacio de anomia y de pura violencia que, no obstante, es esencial para dotar de identidad a la esfera del ordenamiento político-jurídico estatal (177).

En los imaginarios contemporáneos de nuestra década, el confín funciona cada vez más recurrentemente en la figura de una fuente de producción de todo tipo de amenazas para la vida; espacios donde lxs sujetos se ven constreñidos a buscar vías de sobrevivencia en un ambiente de riesgo y peligro general tanto para su propia integridad como, sobre todo, para lxs más vulnerables por el poder arbitrario: mujeres, niñxs, inmigrantes y, más ampliamente incluso, para la naturaleza, para la vida del planeta.

similar piensa la memoria: "Somos cojos, sépanlo / caminamos para un solo lado / Llevamos algo muerto dentro de nosotros / un cadáver que no conocemos" (Lamm 109).

14 Consideradas "geografías de la excepción" (Campesi 177), la vida estaría allí expuesta como vida nuda (en la imagen de Giorgio Agamben: Homo sacer I), y se reproduciría en la incertidumbre y en la constante amenaza de la arbitrariedad. 
Es el caso paradigmático de toda una tendencia en la ficción policial que ha cobrado renovada fuerza en los últimos años, el llamado Nordic Noir, cuyas historias, situadas en escenarios de frontera o del interior remoto, del adentro extraño y desolado del territorio, son protagonizadas por personajes sombríos (muchas veces mujeres - acentuando su vulnerabilidad-), la mayor parte expatriadxs, con pasados por olvidar y secretos a cuestas, que se ven enfrentados a esta violencia irregular del confín.

Mas el vocablo confín es ambivalente. Usamos confín como sinónimo de lugar recóndito y alejado, separado por inmensas extensiones (espaciales e incluso temporales, imaginarias) de nuestro espacio conocido. En los confines pasan las cosas que nos son extrañas, en ellos se materializan nuestros miedos. Sin embargo, etimológicamente confinis marca la contigüidad, la vecindad y la comunidad de un límite común, un "con": la cercanía, al mismo tiempo que el fin, la frontera ${ }^{15}$ (usamos confinar como sinónimo de reclusión). Los confines funcionan de esa manera en nuestro imaginario, en esa ambigüedad, como aquello que nos es extrañamente familiar (que por ello adquiere muchas veces tintes siniestros), que discute e interpela nuestra propia idea de espacio, de lo cercano y lo distante, de lo comprensible y lo que queda más allá de nuestro universo. Michel Foucault perfectamente podría ubicar a los confines en su catálogo de heterotopías, en tanto espacios que funcionan como espejos invertidos de los emplazamientos de la cultura. ${ }^{16}$

Como decíamos arriba, desde la tradición borgeana, los confines funcionan también como las "orillas", es decir, como espacios vinculados a un tiempo especial, descronologizado, muchas veces anacrónico, donde convergen tiempos heterogéneos. En las escrituras que presentamos, es este el tiempo escatológico, de las postrimerías, ese espacial metatiempo que anuncia lo que resta del tiempo y en el que adviene el fin, y que en sí mismo incorpora una especial concentración y partición heterocrónica — por ejemplo, en la lógica del indicio, en la intrusión del mito y del anacronismo—. ${ }^{17}$

¿Qué imaginación de las postrimerías producen estas escrituras chilenas de los confines?

15 Confín deriva del vocablo clásico confinis (contiguo, vecino, que comparte un límite común) o del sustantivo confinium (límite común a dos terrenos) y significa "marcar el límite”. Diccionario Etimológico Castellano en línea. http://etimologias.dechile.net/

16 Para Foucault los "[espacios donde] los emplazamientos reales que se pueden encontrar en el interior de la cultura están a la vez representados, cuestionados e invertidos, especies de lugares que están fuera de todos los lugares, aunque sean sin embargo efectivamente localizables. Estos lugares [...] los llamaré, por oposición a las utopías, las heterotopías; y creo que entre las utopías y estos emplazamientos absolutamente otros, estas heterotopías, habría sin duda una suerte de experiencia mixta, medianera, que sería el espejo" (párr. 12).

17 Foucault apunta que las heterotopías están asociadas al tiempo: "operan sobre lo que podríamos llamar, por pura simetría, heterocronías. La heterotopía empieza a funcionar plenamente cuando los hombres se encuentran en una especie de ruptura absoluta con su tiempo tradicional" (párr. 22). 


\section{Escrituras chilenas de los confines}

En el comienzo de Nancy (2015) de Bruno Lloret, la protagonista, que pasa recuento a su existencia desde su cama de enferma terminal de cáncer, recuerda el momento en que recibió la noticia de la muerte de su marido quien, le explicaron los hombres de la empresa, había sido tragado por las máquinas enlatadoras de pescado y su cuerpo había sido procesado y envasado: "imaginé que [el encargado] contestaba [...] que lo único que podían hacer por mí era darme un momento a solas con la serie de 2.500 latas entre las cuales mi difunto marido estaba repartido" (27). Toda su vida madura, asimismo, Nancy se ha preguntado por el destino de su hermano Patricio, desaparecido un día en la cotidianeidad opresiva de pueblos contaminados por desechos de industrias de cría y procesamiento de cerdos en los confines del desierto de Atacama. Así, nos cuenta que un día cualquiera la policía hacía entrega a su padre de una mano, como de mono (132), y que aunque sabía que no correspondía a la del hijo, no importaba, porque había que darle sepultura a algo. La protagonista se allega a Jesulé, su amor adolescente y recuerda que en sus encuentros trataba de imitar las películas porno, a la vez que observa desde su lecho el escenario de su existencia maltratada. Todo la toca y nada lo hace, pues Nancy narra desde el momento en que está siendo separada, arrancada de sí, cuando le han sustraído la esperanza (la espera) y le van quitando su cuerpo, todos sus cuerpos.

Nancy nos comparte la destrucción del mundo, de todo su mundo, que no ocurre como decadencia porque esa destrucción siempre estuvo allí y ella misma es ese cuerpo desasido: "Nancy-Cáncer". Todo se va perdiendo, y ella con todo, lo único que le queda es esa memoria distante, y unas imágenes. Ella es el fin de sí y de su mundo, la caída que solo puede narrarse desde lejos, como si no estuviera allí. La mujer recuerda observando como tras una cortina, como si ese cuerpo y esa existencia no le pertenecieran: "volví a ser un fantasma" (27). Nancy no toca, se observa en imágenes, lo único tocado es su imagen: como en la radiografía de su cuerpo canceroso, es una imagen de sí que arde o está a punto de arder. Nancy es la desaparición. Es la sustracción del cuerpo y su reducción a partes, falsas: de su marido, de su hermano, del suyo mismo. Nancy niña pasea por playas de arenas oscuras en las que la inminencia del horror le susurra de desapariciones de mujeres en su pueblo abreviado, "Ch", lejos de todo. Pero la Nancy que recuerda ha dejado de coincidir con esa historia que la arroja afuera constantemente. Un pueblo y una historia que la expulsan.

Colmada su existencia a tal punto de esas violencias, la representación de sí de la narradora se convierte en una multiplicación de rajaduras y vacíos, una memoria llena de cruces, de "X", caracteres secretos, incógnitos que parecieran guardar la renovada esperanza de ser signo, de coincidir con algo, pero que se revelan permanentemente solo tajos en la escritura, marcando, por el contrario, la incomparecencia, la distancia, la detención del sentido. La realidad de Nancy es evasiva y traicionera. Se le quita una y otra vez a través de la mediación fría de la vida que es la violencia representacional 
de la ciencia, de la religión, de la familia, del centro metropolitano ante estos pueblos sin poemas. No hay forma de ser, parecieran decir los discursos, si no es en ese régimen memético, que atrapa y repulsa a la vez y que, como un lago viscoso, confunde la comprensión de la profundidad del abismo de la realidad. Una realidad que ha sido, ella misma, transida de espectáculo, organizada en nuestras cabezas como un guion de thriller policial, o de porno: "Y los dolores / Y los maniquíes en la calle / Las viejas con piel de cera / y una volviéndose cartón piedra" (Lloret 26).

Nancy, su historia y ese pueblo de "Ch" funcionan, así, en la reflexión sobre el espacio-tiempo liminar del abandono total, de la destrucción anunciada que lxs abandonadxs solo pueden observar desde su propio final. El confín que es "Ch" se presenta, asimismo, como metonimia del cuerpo-país neoliberal, cuya superficie aparece siempre como la epidermis de otra piel, escondida, cuyas capas inferiores se encuentran infestadas: de cáncer, de putrefacción, de dolor, de miedo; un cuerpo además fragmentado y desrealizado como tal cuerpo en su violencia autopredadora soterrada y por ello pareciera que definitiva, ubicada en el sin tiempo del tiempo del fin. Este otro cuerpo de la provincia, del confín, del pueblo sin nombre, se ha vuelto así la parte ocluida y separada, que se observa como unx niñx locx, con los ojos del otrx separado, y que comparece ante el cuerpo nacional como resto extraño, expulsado, solo visto a través de sus imágenes e imaginerías: radiografías, películas noir, publicidad. Nancy, en el fin, denuncia el suyo como un cuerpo restante que ha querido ser desapropiado, observado en ojos extranjeros, y sucesivamente demolido (y procesado) como tal espacio-tiempo impropio del confín.

Como si su historia misma fuera una memoria apócrifa, falseada, en Nancy el fin del mundo es el fin de todos los mundos de otras mujeres en esos pueblos abandonados a la violencia; y su propia historia aparece como imposible de asir a pesar de toda la violencia, una historia como un tajo abierto, pues no vuelven su cuerpo, sus cuerpos perdidos, desaparecidos.

En "Rinconada”, un cuento de Eslovenia (2014), de Esteban Catalán, todo pareciera anunciar el desastre que sobrevendrá, en un presente que zozobra y que es el conteo en reversa del fin, a esxs jóvenes que venden pasta base y comparten sus sueños en medio de un ambiente de inercia en la marginalidad. Así, el narrador, lejano, pasa recuento por encima a situaciones que son indicios de la catástrofe que viene porque marcan su tiempo. Así, la última visión del cuerpo ágil y gracioso de su amigo, el Choco, que "iba bailando, al frente de nosotros [...que] Podía inclinar una parte del cuerpo como un dibujo animado [...] entonces caminaba, con elegancia, delante de nosotros" (110-111). Porque -él ya lo sabe cuando narra - el Choco ha perdido su pierna en la violencia de la calle, y con ella, le ha sido usurpada esa inteligencia fina del cuerpo que se solaza y se inviste de elegancia y sutileza, que era en él ese espacio/tiempo que recusaba el fin necesario que exige la marginalidad. Porque se sabía, en el fin, que esa juventud marginal del Choco no tenía derecho a ese solaz, a ese baile, a ese cuerpo: "El Jano me contó después todo, por teléfono: la pega que hicieron juntos, las barricadas, cómo 
sonó el hueso, el tobillo del Choco destrozado, la quemadura en los bordes, la carne viva" (111). Más “indicios": el narrador luego nos cuenta sobre las niñas asesinadas que aparecieron en la población. Marcadas simbólicamente, como señas inequívocas del fin: "Encontraron a dos niñas muertas, con las extremidades inversas, niñas morenas con las ancas mirando hacia el cielo, las cabezas hundidas en el piso y leyendas pintadas en los muslos. Como pirámides bastardas, decía el cantar de una de las Madres" (114). Mientras, los padres se encontraban borrachos o viendo TV (120). Y todo ello, como un compás regular de la música que va marcando la cercanía del final, cuando todo iba a explotar y comenzaría otra historia: "Ese día fue el único que se pudo ver al cellista en la tele, antes de que empezara todo, cuando saltaron los niños sobre el set con cuchillos, como monos, sobre las damas del tiempo, maniatándolas con cierta belleza, de espaldas al espectador" (120). La marginalidad está destinada al fin, y sus sueños son las pesadillas de todo el ordenamiento de los espacios y los tiempos de ese último tiempo que nos resta. En la heterotopía de la ruptura se deshacen todos los indicios que debieron concluir en un final predicho, en este cuento de Eslovenia (el territorio distante y recóndito sobre el que les cuenta TV al protagonista y a su madre que "Siempre tiene la televisión encendida" $(19)^{18}$ ).

En Bagual (2014) de Felipe Becerra, son justamente lxs niñxs no-natxs de nuestras pesadillas quienes abren la visión de la profundidad del mal en el rincón de la patria y de la psiquis. En Huara, un pueblo en medio del desierto atacameño, cuyxs habitantes "parecen estatuas" (103) o fantasmas, se consuma la pesadilla de seres que vienen cargando desde otras geografías sus historias y esperanzas de nuevos comienzos pero que en ese confín son expuestos, sus cuerpos y sus mentes, desnudos, ante la luminosidad extrema ${ }^{19}$ que no permite guardar secretos ni miedos. Entornos macabros donde el horror acecha agazapado y personificado por niñxs-monstruos y perros salvajes que son "vestigios del futuro" (87), últimxs habitantes de un mundo que ya está muerto en el interior de nuestro cuerpo y en el afuera de nuestras pesadillas, y que camina sin darse cuenta como perdido (loco perdido): animales y niñxs que han gastado toda inocencia y que se dedican a alimentar nuestras pesadillas, inoculadas por un poder que lxs y nos supera. Y por profetas como el Profesor Destino, conocido por los militares de esa frontera como "Doctor Tormento" debido a sus labores para la institución, que incluían el especial método de extracción de información a través de la tortura psíquica por inoculación de espantosas pesadillas. Así, el teniente de Carabineros Carlos Molina nos narra el proceso de instalación en ese confín, sus expectativas y su imprecisa aunque creciente sensación de que el horizonte iba siendo cubierto por

18 El relato "Libro de ilustraciones". En él, un joven que nos cuenta que "el trabajo de mi carrera era una serie de dibujos sobre animales del bosque en movimiento y quedé con una deuda de tres millones de pesos" (18) y en el futuro, él y la madre miran documentales sobre Eslovenia en una población del margen de Santiago.

19 "Toda escatología apocalíptica se afirma en nombre de la luz, del vidente y de la visión, y de una luz de la luz, de una luz más luminosa que todas las luces que ella hace posibles. El apocalipsis de Juan que domina toda la apocalíptica occidental se ilumina a la luz de Él, de Elohim [...]” (Derrida párr. 55). 
la definitiva imposibilidad, un espejismo, una mancha visual, un gran alacrán que comienza a llenar su perspectiva y que se asemeja a las montañas de la locura. Todo ello le va provocando una sensación de absurdo "que pronto se convierte en asco" (103-104). Mientras, su mujer, Rocío, desde antes que él ha dejado de dormir, víctima de recurrentes pesadillas en las que lxs niñxs locos, no-natxs de su pasado se dedican a intervenir sus recuerdos, enlodándolos de las peores formas, llenando todo de miedo, para impedirle el futuro, para hacerle perder la razón en la geografía sinuosa de ese pueblo aislado, que se convierte para ella en el final, en su destino, como el Doctor.

En las cavernas oscuras de su psiquis colonizada, sin embargo, la mujer encuentra la posibilidad de otro derrotero, inmersa en el pozo de sus mayores miedos. De tal manera, en uno de sus sueños, ya en el "cogote de un animal tremendo [o] las tripas de un monstruo" (127), llega hasta una cueva repleta de momias, "Las momias lloran. Las momias aúllan y se chupan las manos de polvo. Las momias dicen cosas tristes. Cuentan que las mataron. Todas juntas cuentan que las enterraron vivas" (128-129). A ese lugar espeluznante les ha conducido, a la mujer y a sus hijxs-monstruos no-natxs, un niño indio que oficia de mensajero que comunica con ese tiempo antiguo, negado, que ahora retorna pero no ya como pasado, sino como presente, como potencia de interpelación que habla en ella y por ella, e incluso más, como futuro, porque como afirman lxs hijxs perdidxs de su imaginación, esas son aunque "imágenes de realidad, imágenes de espanto [...] Es el futuro, eso sí está claro” (131). Un futuro que es, anacrónicamente, el del tormento antiguo, largo y continuo a esos cuerpos inocentes, atraído por un niño indígena. El futuro se les presenta, luego, en otra imagen, una inmensa torre postapocalíptica de miles de pisos, habitada por niñxs solxs, por un ejército de niñxs solxs y mutiladxs, muchxs de lxs cuales habían perdido sus ojos (131); y al lado de la que se desplegaba un bosque oscuro en el que los padres y las madres de esxs niñxs vagaban llorando (131), ciegxs y sin lenguas, padres condenados por sus pecados, que habitaban el purgatorio sin destino; mientras, el ejército de niñxs se desplegaba por la ciudad infantil "como una chorrera de insectos [... y] festejan chapoteando en esa inmundicia" (132), en una ciudad en la que se dan cuenta, sin embargo, de que están absolutamente solxs, y de la que deben ser salvadxs. Y entonces, en el sueño, nuevamente hay perros, perros que también sueñan y que sueñan con la forma de salvar a lxs niñxs (132-133). Y los quiltros cargan a lxs niñxs en su hocico y "los tranquilizan murmurando; llegaremos al lugar al que ustedes pertenecen [...] Ese lugar es la esquina del mundo [...] ¡Un faro en la cola del mundo!” (133-134). Un lugar, en esa esquina del mundo, donde finalmente, aunque plantas carnívoras devoran parte de sus cuerpos infantiles, lxs niñxs encuentran su hogar y, por ello, aun mutilados, "saltan de alegría y abrazan a sus perros con lo que les queda de cuerpo" (134). El futuro está allí, en esa punta del mundo donde los cuerpos rotos se permiten recomenzar en el afecto inocente que le otorgan sus compañeros de ruta, esos perros que al tomarlos en sus hocicos los reconocen: "ustedes, los que abrazan nuestros cuerpos" (133). 
El mistagogo "Destino" es acá un ser ominoso que inocula sueños terribles en sus "iniciados", sueños que se apoderan de sus mentes impidiendo el futuro; pesadillas que, sin embargo, son conjuradas por aquellas voces que retornan desde lejos: el pequeño indígena que conduce a Rocío hacia esxs otrxs niñxs, mutiladxs, que resisten a la soledad; o lxs onas que, a su vez, acompañan a Carlos en su barca a sus infiernos y hacia otros perros, los perros que le hacen ofrenda del secreto del rezo indígena: "serás hijo de ti mismo [...] serás hijo de tu hijo" (144). Ese es el futuro, el vaticinio fiable: el canto del perro. En "esta noche tan moretoneada" (155), donde el peor sueño es que a la pesadilla siga otra pesadilla, es necesario sacar el último sonido de este mundo, para abrir otro mundo, al otro lado, en otro universo, "después de este vacío interminable" (156).

En Yo soy un pájaro ahora (2018), de Vladimir Rivera Órdenes, las historias que se desarrollan en el confín de un impreciso sur austral chileno (entre la isla de Chiloé, Aysén y Magallanes), donde ese mismo año se habían registrado ya dos lluvias ácidas (15), ocurren en el exacto momento en que se ha desatado la catástrofe: ambiental (llamada "Holodomor"), social y personal de lxs protagonistas, de un daño que no tiene contorno, donde "el infinito de la amenaza ha roto todos los límites" (Blanchot 9). Así, en el cuento que da título al volumen, un padre nos anuncia que su hijo de siete años se ha suicidado. Del niño solo sabemos que era introvertido y que vivía en un estado de extrema visibilidad, "Agregó que siempre veía todo, que estaba seguro que dormía con los ojos abiertos" (14). El desastre personal ha devastado al protagonista que está absolutamente solo en el mundo, separado de su mujer luego de la muerte del niño, se siente un fantasma, fuera de la vida: "Entonces piensas que eres inmortal, porque ya nada vive, ni tú, ni él, ni nosotros" (15). El hombre trabaja en una planta procesadora de pollos, que parecía ser el alimento casi exclusivo de la población en tiempos en que el desastre ecológico ha reducido los trabajos e impera el hambre. Cuando una joven trabajadora de la planta intenta robar un pollo para alimentar a su hermano pequeño, el hombre debe dejarla recluida. La inhumanidad y una sensación de pudrición lo inunda todo: las relaciones humanas, el ambiente, el alimento. Acuciados por la necesidad, lxs miles de operarixs de la planta, congelándose, deben, sin embargo, quedarse allí, "quietos, cada uno en sus puestos, como sombras químicas en espacios vacíos, como virus en estado latente" (19) cuando un virus transmitido por pollos infectados amenaza el orden y la empresa. El virus se expande luego, porque sabemos que la planta se irá quedando vacía "como Detroit luego de la debacle. [Y que...] Tiempo después la llamarían Holodomor" (24). Los presagios se intensifican: sombras, perros a la orilla del camino, mariposas, hasta que el hombre, impávido, es testigo de cómo la gente va cayendo desplomada envuelta en llamas: "Arden" (30), y él, trabajador del control de calidad en la planta, se siente entonces libre porque ya no iba a controlar más nada, pues estaba en el final: ahora soy un pájaro, dice.

En el relato "La miseria es una mariposa", Manuel, también operario de un frigorífico de pollos, se ha contagiado de una extraña peste que está acosando a los 
hombres de su pueblo: pierden el semen. El hombre, que se alimentaba de pollos y "ñoco" (neoprén), viendo que los obreros a los que se les identificaba como infectados eran abandonados al hambre, intenta eludir los controles médicos de la planta. Y allí, en ese confín donde "La sangre de un cerdo no se diferenciaba mucho de la de un humano" (Rivera Órdenes 47), busca una salida a través de la relación sexual con su perro, como había hecho otro contagiado antes que él, puesto que allí, "en el fin del mundo [...] todas las razas confluían" (49). Hacia el final, se nos cuenta que el hombre "Soñó con perros en celo en el fin del mundo. Soñó con un hada y un duende y un niño muerto en una hambruna” (43).

En el cuento "Perros a la orilla del camino", una familia es acechada en su hogar por jaurías de perros salvajes; el miedo les impide toda posibilidad de razón y de afecto. Los perros son aquí la vanguardia agresora para que extraños seres sustraigan a uno de sus hijos y a la mujer, desapareciéndolos en razón de un enigmático rito cuyos sintagmas no logran descifrar. Así, "un hombre muy delgado, manos largas, ojos rojos y un sombrero" (Rivera Órdenes 81 ) pide al protagonista que le entregue a su mujer. La mujer es tomada y desaparecida, al igual que el hijo. El presente ha sido inundado por la amenaza infinita: "Tenía miedo, mucho miedo. El futuro era una nube envenenada" (82), declara el padre. Entonces, en ese final del fin ya nada tiene sentido, incluso cuando una sombra se lleva a su mujer y a su hijo:

Miro por la ventana. Se ve cómo los perros corren por otros campos. Se ve fuego a lo lejos. La ciudad se quema. Nada tiene valor realmente. Ni la casa, ni el auto, ni Camila; ni las renuncias que hice año tras año para que esto funcionara. Solo resta el miedo. El olor del miedo (87).

Finalmente, en "Sombras en el piso frío de Chamiza", ya no quedan casi cuerpos, solo sombras (Rivera Órdenes 91), los cuerpos mismos han sido sustraídos en la muerte y se transforman en sombras. Todo ello ocurre en el momento en que la ciudad agoniza, y cada situación cotidiana es indicio del fin que lo inunda todo cuando ya es la catástrofe: “ocurrió el Holodomor y comenzó la diáspora patagónica. Los mares se habían contaminado, de la tierra se desprendía olor a azufre y fósforo. Algunos campos comenzaron a arder y luego el hambre" (101). En un único gesto resistente, la protagonista, Amanda, que sueña con perros albinos salvajes (103), intenta escapar, mas la sombra la devora, cuando su última esperanza era el fuego, prender todo y salir, y su muerte llega a destiempo, en el desastre que no espera: "Respecto del desastre, se muere demasiado tarde" (Blanchot 11).

Interconectados en este confín del sur austral chileno, los relatos de Rivera Órdenes se ubican en el tiempo ambiguo del antes del desastre que es su propia inminencia, una amenaza infinita que no tiene un afuera, que no deja ver su límite: "Estamos al borde del desastre sin poder ubicarlo en el porvenir: más bien es siempre pasado y, no obstante, estamos al borde o bajo la amenaza, formulaciones éstas que implicarían el porvenir si el desastre no fuese lo que viene, lo que detuvo cualquier venida", explica 
Blanchot (9). Los relatos ocurren justamente en ese intertanto que es un tiempo que espera convertirse en pasado pero que no pasa, que pretende ser futuro pero que está aquí, desenroscándose y atrapándonos, pues se está desarrollando como crisis, como la inminencia que no deja de pasar, que no transcurre y que es una amenaza en el horizonte, el Holodomor, pero a la vez son los perros rabiosos que acechan, es la luz que lacera y que no termina por cegar. ${ }^{20} \mathrm{Y}$ de nosotrxs es la absoluta impasividad y confusión, porque no tenemos palabras, ya no hay lengua para producir las cisuras, los bordes de las cosas y los lugares, porque no tenemos adónde escapar ni dónde encontrar cobijo. El apocalipsis que pone en marcha Órdenes es eso: el fin de todo en el fin del mundo, donde no hay más mundo porque ese confín ha espejeado el absoluto del desastre. No hay parámetros, todo se ha cumplido y a la vez está por cumplirse como amenaza. Estamos esperando Holodomor y estamos en él, somos él, dicen estas historias: ya no cuerpos, sino sombras, sombras que sustraen cuerpos en la noche mientras el mundo arde.

Estas escrituras chilenas de las postrimerías narran el desastre como tal inminencia que ya está aquí, acechando, en los escombros de nuestras ciudades, como anuncio de la destrucción que ya ha ocurrido. Son, en la imagen del poema de Jonnathan Opazo, esos, "Los suicidas / [que] son los frutos / maduros de los / rascacielos" (Junkopia s. p.), que convocan un futuro que, como él mismo enseña, "no es otra cosa / que los escombros / del presente" (Junkopia s. p.).

Sabe el poeta que nos extinguiremos, y, como aquel fiero crítico que le antecedió en otro fin de mundo, ${ }^{21}$ imagina la postrimería como un tiempo en el que ya no existirán más que las ruinas de lo que fuimos, unas ruinas patéticas que nadie descifrará como huellas, mensajes a nadie porque ya no habrá nadie que pueda oírlos, sobre la inmensa vanidad del ser humano: "Desaparecemos de la tierra" anuncia, "y eso debería aliviarnos", continúa, "las ondas de radio / seguirán viajando a través / de kilómetros y kilómetros / de vacío: así son nuestros / escombros: corredores de / primera categoría en las / olimpiadas del tiempo". Y la civilización serán los sonidos que registramos en máquinas que quisimos controlar y que nos permanecerán, “entonces: desapareceremos / de la tierra. el sonido será / el único poema que sobreviva: / una conversación telefónica / o el discurso histérico de / un protestante en una / solitaria radio a.m. / Londres llamando / desde alguna parte / Neruda declamando / el último discurso / de Hitler antes de / la caída, Alemania / año 1945" (Opazo, Baja fidelidad 30-31).

20 "Noche, noche blanca — así es el desastre, esa noche a la que falta la oscuridad, sin que la luz la despeje-", es la imagen de Blanchot (10).

21 Me refiero a Karl Kraus. En su "Apocalipsis", carta dirigida a los lectores de Die Fackel, a fines del 1908, apunta: "MI religión es creer que el manómetro marca 99. Los gases del estiércol cerebral del mundo atraviesan todo desenlace, a la cultura no le queda respiro y al final yace una humanidad muerta junto a sus grandes obras. Del enorme ingenio que ha empleado en construirlas ya no le queda nada como para seguir utilizándolas" (30). 


\section{La fragilidad critica del presente}

Esos escombros, esos trozos de la civilización caída, sin embargo, nos atraen, ¿por qué? No tanto, digo, porque se lleven con ellos el secreto de las grandes obras, sino más bien porque de alguna manera nos permiten intuir las PEQUEÑAS: nuestras virtudes cotidianas y nuestros defectos, nuestras trivialidades, nuestras incomparecencias, nuestros gustos inexplicables, nuestras MATERIAS. En esos RESTOS, en los pequeños vestigios de nuestra existencia, allí se queda nuestra vida plena aunque a trozos, a GIRONES; esa VIDA que de todas maneras es indiscernible en el continuo que es la historia, esos secretos que solíamos contarnos a nosotros mismos como ritos o como JUEGOS. Por eso nos gustan las animitas, y todo lo vamos volviendo ANIMITA, y por eso en nuestra última revuelta no fue raro pegar muñecas y juguetes y TRAPITOS y PAPELES y todo tipo de mensajes a las paredes, pegarlos y colgarlos al CUERPO de las PAREDES, de la calle: sacar los trapos al sol. Ya no bastaba con rayar, teníamos que llenar las paredes de nuestras pequeñas MATERIAS RUINOSAS, de nuestros detalles y bisuterías, de nuestros recuerdos, e insignificantes obsesiones, cuyo sentido personal ahora queríamos poner al lado de otros sentidos; como hacen lxs niñxs y que tan lúcidamente observó Walter Benjamin. Porque el futuro que rompe la repetición del presente también se abre con las materias, cosas PEGADAS a otras cosas, aglutinadas: RESIDUOS del pasado, recuerdos y cajones que vamos abriendo para COSERLOS a otras cosas, colecciones, diminutas HEREDADES.

A propósito del impulso utópico, Fredric Jameson ha propuesto que la función política de la utopía "consiste precisamente en interrumpir y/o romper nuestras ideas heredadas al respecto del futuro: romper ese futuro prefabricado" (72) y nos recuerda que para Ernst Bloch, en la base del "principio esperanza" se encontraba este impulso utópico, que es la fuerza activa por antonomasia, la fuerza política.

Los multipatópodos (2017), un hermoso libro reciente de Yosa Vidal (con ilustraciones de Luis Vidal) nos brinda un bestiario de distintos seres que, en un futuro avanzado del siglo xxI, han nacido a pesar de e incluso en la contaminación, en lupanares químicos en las costas del océano Pacífico. En estas postrimerías, luego del desastre ecológico en la Tierra, la vida se ha multiplicado y, cultivados en el azufre y líquidos ácidos, estos extraños nuevos seres han proliferado. Diversas especies surgieron y de la inmundicia, e incluso la destrucción, el mundo siguió su curso. De entre estos seres, algunas especies que merecen especial mención son, por ejemplo, el Diplócaro o Comedor de sí (Narcisus autófago). Dedicado a la contemplación de su imagen, es un ser que a veces, después de las largas jornadas de autocontemplación, se da a devorar su propio cuerpo con fruición (11-13). Otro muy especial (aunque todos son únicos) es el Cantón Suicida (Avis aranae perniciosa), "hijo íntegro de la revolución" (17), que apoyó desde siempre la producción de tela de araña en servicio de la fabricación de ropas blindadas para la guerrilla; los cantones son de un compromiso absoluto con su causa, y prefieren suicidarse antes que entregar 


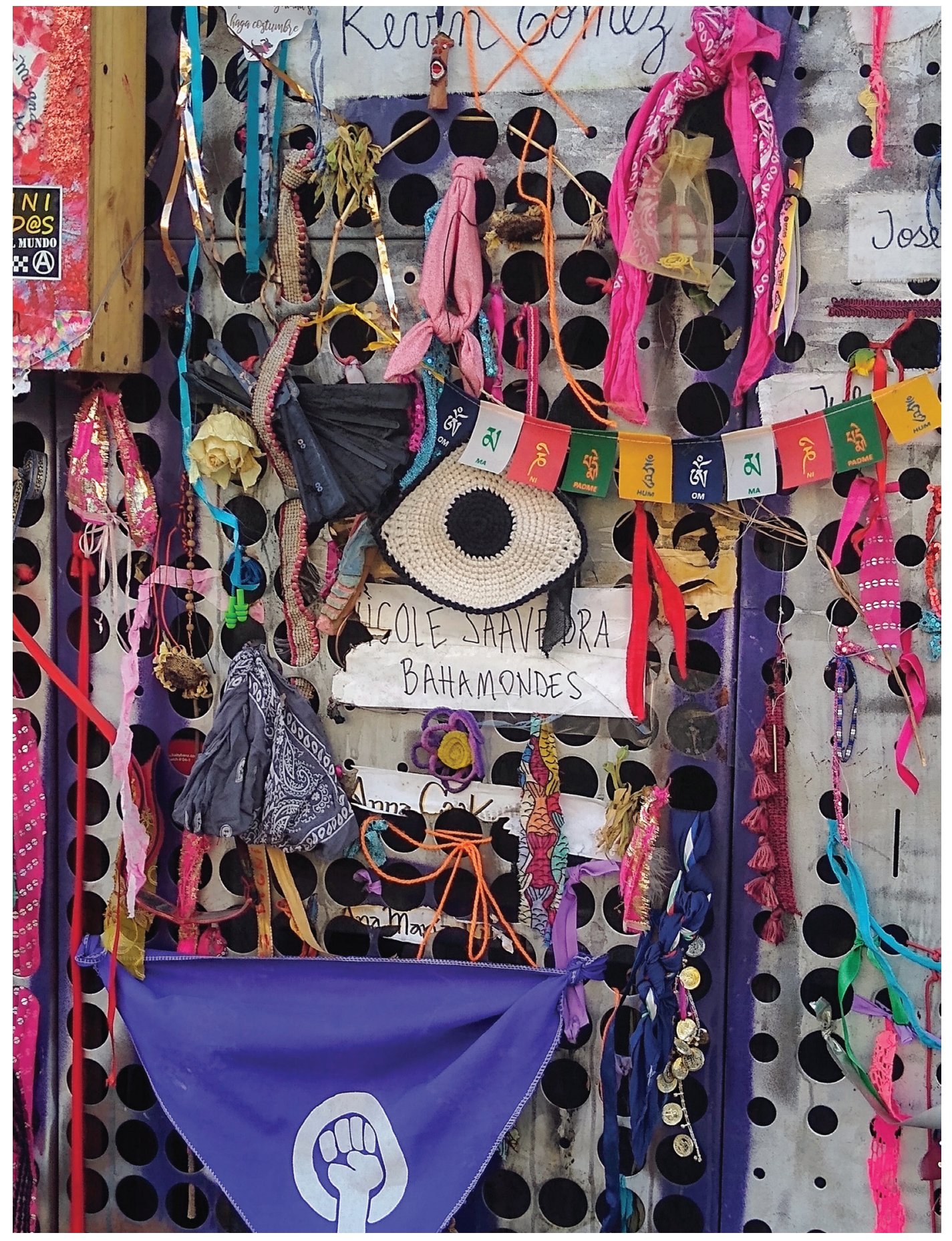


sus armas al imperio. Digno de recordar es asimismo el Iconoclastópodo, que tiene aversión a todo tipo de emblemas de autoridad, y "destruye pinturas sagradas, íconos religiosos y todo tipo de monumentos", de hecho, "una vez que detecta un monumento, se abalanza sobre él para orinarlo, morderlo, rasguñarlo y escupirlo con una rabia ancestral" (23); este animalito que no soporta tampoco a lxs intelectuales que se estiman en mucho, se alimenta de basuras y de cualquier cosa que le den. También llamativo es el Metanón, cuya razón de ser es procesar la fermentación del ambiente, esto es, todo tipo de basuras del aire, de la tierra, del agua, que devuelve en forma de gas metano inodoro y que permitió volver a oler la tierra a habitantes de pueblos de frontera hundidos en la suciedad. Interesa mucho también el Otario Pincoy o Guapo de Bolsa, una especie de pez que vive en los mares al sur de Chiloé y cuyo origen habría sido una fuga de salmones de criadero que en su escapada se cruzaron con chungungos; estos pincoyos viven en y entre los abismos marinos (34). Vale igualmente mencionar al entrañable Torreón, un animalito que vive cerca de las torres de alta tensión y que es altamente vulnerable y sufre de permanente dolor moral y físico, es muy vergonzoso y también miedoso. Como en los textos del género en la Edad Media, añade el catálogo su correspondiente epílogo con las siguientes sentencias: "La vida se ha mantenido [...] por el azar y el esfuerzo que cada una de las especies hace para sobrevivir". Los Multipatópodos "han sobrevivido y se han desarrollado como el antepasado común que nos entregó la sentencia ineludible de la mutación" (72).

He querido no dejar de recoger en esta reflexión sobre las escrituras chilenas de las postrimerías este amoroso bestiario fantástico postapocalíptico que nos regala Yosa Vidal porque pienso que su modo utópico de acercarse al futuro puede ser, asimismo, otro signo de las formas que han estado en juego en la actual crisis, que pareciera tampoco contentarse con la sola advertencia crítica y quisiera poder imaginar otros futuros posibles. Esta imaginación utópica de Yosa Vidal resulta política en la misma medida en que la utopía representa, hoy como ayer, la manera privilegiada de salir de los marcos de continuidad que han puesto consuetudinariamente a unas cosas vinculadas de manera necesaria a otras cosas. Dice Fredric Jameson: "creo que sólo los utopistas proponen una verdadera alternativa al sistema: la utopía es, de hecho, un intento de imaginar una auténtica alternativa al sistema, y hoy día éste es el genuino espacio para la política, mucho más de lo que jamás lo ha sido" (68). Pues si el desastre es lo radicalmente separado, ${ }^{22}$ la postrimería que imagina utópicamente de nuevo, retoma la unidad, reconstruye el TEJIDO de la imaginación, enreda y repone la creación. ${ }^{23}$ CREA su MILAGRO.

22 El “desastre está separado, es lo más separado que hay”, afirma Blanchot (9).

23 Como tempranamente afirmó Lewis Mumford: "Nuestra elección no es entre la eutopía y el mundo tal como es, sino entre la eutopía y nada. O mejor, la nada. Otras civilizaciones se mostraron hostiles a la vida buena y se hundieron y desaparecieron. Únicamente nuestra voluntad-de-eutopía nos impedirá seguir su camino” (250). 
En Cardador (2019), de Natalia Rojas, el poema nos cuenta de la renovación, cada amanecer, pero también en los diminutos resquicios de vitalización durante el ciclo diario, de la vivacidad de una naturaleza que pareciera habitar en una dimensión cercana pero independiente del ser humano. La tarea del/la cardador/a y su fino trabajo de PEINADO, separación y emblandecimiento de las fibras para el tejido, concuerda en una CONTINUIDAD singularizada con cada uno de los seres vivos que aportan su paso en la DANZA espontánea de la renovación de los ciclos. Así, todas las materias son parte orgánica de una hazaña vital donde no puede comprenderse la cisura, ninguna cisura, pues cada una de esas LABORES está continuada por la otra que le sigue necesariamente:

el agua en el espejo es hilera de fuego, la figura arde y dibuja contornos en la tierra árida. las piedras de agua en los ojos del viento, curvan la llegada. la luz que se quema consigue hacernos recordar el olor al amanecer. las flores, a esta hora, salen del frío conducidas por la luz. el botón de la flor, primero es una piedra, pero ángel de la piedra, líquida, licuada con el vacío. el botón no necesita salir del frío para conocer al sol, es piedra sol adentro hasta que con completa voluntad, el agua y el fuego la llaman, la llamean, sal al sol, sal, piedra hasta un mar

las flores abren y la hoya hidrográfica del mundo aumenta (Rojas 18)

\title{
La crisis
}

\author{
Por un segundo \\ edificios, plazas y \\ calles lucen verdes ante \\ el estallido de los \\ fuegos artificiales \\ (Opazo, Junkopia)
}

Sometidxs como estamos hoy a un régimen en que la liquidación física por parte del Estado se ha vuelto nuevamente parte del horizonte de posibilidades verosímiles, inmediatas y cotidianas, ${ }^{24}$ en que esa cotidianeidad nos recuerda cada vez con mayor nitidez que "el gesto que inicie el Apocalipsis no diferirá de ningún otro gesto" (Anders,

24 El día 2 de octubre de 2020, un joven chileno de diecisiete años fue arrojado al río Mapocho por un funcionario de Carabineros de Chile. El joven perdió el conocimiento al golpear su cabeza contra el lecho del río y fue salvado de la muerte por otrxs jóvenes manifestants y por paramédicxs de las brigadas de salud movilizadas desde octubre de 2019. Ello ocurrió en el contexto de las protestas por la conmemoración de un año del inicio de la revuelta chilena, en las inmediaciones de la Plaza Dignidad (así llamada por el pueblo chileno en rebeldía). La Oficina para América del Sur del Alto Comisionado de las Naciones Unidas para los Derechos Humanos solicitó una investigación exhaustiva sobre el caso. 
cit. en Bauman 199) y que toda la maldad puede anidar en cada gesto cotidiano de agresión al otro, estas escrituras chilenas de las postrimerías se preguntan y escriben el fin de los tiempos y las amenazas que se ciernen sobre la vida nuestra, y desde allí no solo producen la crítica y la alerta sobre el presente, sino que, en muchos casos, gracias a la apertura de nuevas asociaciones a la vez con el pasado y con la experiencia de esos confines descartados por el centro del ordenamiento como residuales, permiten nuevas elaboraciones sensibles que interceptan dislocando, los límites de nuestros imaginarios de lugar y de tiempo.

Y aprendemos, así, junto con el pulso imperativo de las preguntas que nos hacen, dónde y cuándo se puede terminar nuestro mundo. Dónde y cuándo se está acabando nuestro mundo. Y que vivir en la crisis es hacerlo en la consciencia de ESTAR-SIENDO LA CRISIS, habitando la frágil y peligrosa escena de estos confines, en la vivencia del FIN DE UN MUNDO.

\section{Referencias}

Agamben, Giorgio. El fuego y el relato. Trad. Ernesto Kavi. Madrid, Sexto Piso, 2016. - - Homo Sacer I: El poder soberano o la nuda vida. Trad. Antonio Gimeno Cuspinera. Valencia, Pre-Textos, 2010.

Bauman, Zigmunt. Daños colaterales. Desigualdades sociales en la era global. Buenos Aires, Fondo de Cultura Económica, 2011.

Becerra, Felipe. Bagual. Santiago, Sangría, 2014.

Benjamin, Walter. Reflexiones sobre niños, juguetes, libros infantiles, jóvenes y educación. Buenos Aires, Nueva Visión, 1974.

Blanchot, Maurice. La escritura del desastre. Caracas, Monte Ávila, 1990.

Bottinelli, Alejandra. "Narrar (en) la 'post': La escritura de Álvaro Bisama, Alejandra Costamagna, Alejandro Zambra”. Revista Chilena de Literatura, n. ${ }^{9}$ 92, 2016, pp. 7-31.

Campesi, Giuseppe. "Migraciones, seguridad y confines en la teoría social contemporánea”. Revista Crítica Penal y Poder, n. ${ }^{o} 3,2012$, pp. 166-186.

Catalán, Esteban. Eslovenia. Santiago, Montacerdos, 2014.

Contardo, Óscar. Antes de que fuera octubre. Santiago, Planeta, 2020.

Corominas, Joan. Breve diccionario etimológico de la lengua castellana. Madrid, Gredos, 1987.

Derrida, Jacques. Sobre un tono apocalíptico adoptado recientemente en filosofía. Trad. Ana María Palos. México, Siglo xxi, 1994. Disponible en: https://redaprenderycambiar.com.ar/derrida/textos/apocaliptico.htm (Revisado 12 de octubre de 2020).

Didi-Huberman, Georges. Ante el tiempo. Historia del arte y anacronismo de las imágenes. Buenos Aires, Adriana Hidalgo, 2006. 
-_. Falenas. Escritos sobre la aparición 2. Santander, Shangrila, 2015.

Foucault, Michel. "De los espacios otros" ["Des espaces autres". Conferencia en el Cercle des études architecturals, 14 mar. 1967. Architecture, Mouvement, Continuité, n. ${ }^{\circ}$ 5, 1984]. Trad. Pablo Blitstein y Tadeo Lima. Fotocopioteca, n. ${ }^{\circ}$ 43, 2014.

Guattari, Félix y Suely Rolnik. Micropolítica. Cartografias del deseo. Trad. Florencia Gómez. Madrid, Traficantes de Sueños, 2006.

Jameson, Fredric. “Arqueologías del futuro". El viejo topo, n. o 219, 2006, pp. 68-73.

Koselleck, Reinhart. Crítica y crisis. Un estudio de la patogénesis del mundo burgués. Madrid, Trotta, 2007.

Kraus, Karl. “Apocalipsis (Carta abierta al público)”. Apocalipsis. Trad. Natalia I. Vidal. Buenos Aires, Godot, 2015, 29-55.

Navarro Geisse, Fernando. "Los habitantes del fuego". Los hijos suicidas de Gabriela Mistral: antología poética de escritores jóvenes del Valle de Elqui. Antologador Leonidas Lamm. Valparaíso, Inubicalistas, 2010, pp. 71-77.

Le Goff, Jacques. El orden de la memoria: el tiempo como imaginario. Trad. Hugo F. Bauzá. Barcelona, Paidós, 1991.

León, Gonzalo. La caída del jaguar: crónica del estallido social en Chile. Prólogo Horacio González. Buenos Aires, Hormigas Negras, 2020

Lloret, Bruno. Nancy. Santiago, Cuneta, 2015.

Mumford, Lewis. Historia de las utopías. Trad. Diego Luis Sanromán. La Rioja-España, Pepitas de Calabaza, 2013 [1922].

Opazo, Jonnathan. Baja fidelidad. Santiago, Jámpster eBooks, 2017.

Opazo, Jonnathan y Rodrigo Figueroa. Junkopia. Talca, Bifurcaciones, 2016.

Oviedo, Antonio. "Nota preliminar". Ante el tiempo. Historia del arte y anacronismo de las imágenes, de Georges Didi-Huberman. Buenos Aires, Adriana Hidalgo, 2006, pp. 11-28.

Rivera Órdenes, Vladimir. Yo soy un pájaro ahora. Santiago, Montacerdos, 2018.

Rojas, Natalia. Cardador. Arica, Aparte, 2019.

Sarlo, Beatriz. Borges, un escritor en las orillas. México: Siglo XXI, 2007.

Stern, Nano. Ilustraciones, Marcelo Escobar Morales. Décimas del estallido: crónica en verso de la rebelión chilena. Santiago, Cuño Editor, 2020.

Vidal, Yosa. Ilustraciones, Luis Vidal. Los multipatópodos. Santiago, Overol, 2017.

Enviado: 28 de octubre de 2020

Aceptado: 8 de diciembre de 2020 